\title{
Habitat, food, and small mammal community structure in Namaqualand
}

\author{
M. VAN DEVENTER and J.A.J. NEL
}

Van Deventer, M. and J.A.J. Nel. 2006. Habitat, food, and small mammal community structure in Namaqualand. Koedoe 49(1): 99-109. Pretoria. ISSN 0075-6458.

The effect of habitat differences and food availability on small mammal (rodent and elephant shrew) species richness, diversity, density and biomass was investigated in Namaqualand, South Africa. Species richness in the three habitats sampled, namely Upland Succulent Karoo, Dry Riverine Shrub and North-western Mountain Renosterveld was low, with only $2-4$ species per habitat. Rodents trapped were predominantly Gerbillurus paeba and Aethomys namaquensis, with fewer Mus minutoides and Petromyscus sp. The only non-rodent was the elephant shrew Elephantulus edwardii. Ten habitat features, the percentage of total plant cover, tree cover, shrub cover, grass cover, plant litter, total basal cover, sand, gravel or rock cover, and the dominant plant height were recorded at 30 randomly chosen points on five sampling grids in each habitat. Small mammal density and biomass was significantly correlated with food availability (green foliage cover, seeds, and relative density and biomass of insects). Species richness and diversity of small mammals were significantly correlated with shrub cover. Numbers and biomass of specific species correlated significantly with different habitat features in each case.

Key words: Habitat features, small mammals, species richness, diversity, Namaqualand.

M. van Deventer and J.A.J. Nel $\varangle$, Department of Botany and Zoology, University of Stellenbosch, Private Bag X1, Matieland, 7602 Republic of South Africa (jan@sun.ac.za).

\section{Introduction}

Small mammals, especially rodents, are often abundant, widely distributed and important components of nearly all terrestrial ecosystems, especially in semi-arid or arid areas (Brown et al. 1986; Price \& Jenkins 1986; Kerley \& Erasmus 1992). Rodents are consumers of both seeds and herbage (Price \& Jenkins 1986; Kam et al. 1997) and also serves as prey to carnivores. Although often omnivorous (Landry 1970; Kerley 1992a), they can also be predominantly granivorous, especially in semi-arid and arid ecosystems (Brown 1975; Mares 1976; Brown et al. 1979; Bar et al. 1984). The degree of granivory differs between deserts, being higher in North American and Israeli deserts than in South American, southern African and Australian deserts (Kerley 1992a, 1992b). Coexistence of granivorous rodent species can be facilitated by size differences (Bowers \& Brown 1982), although in some cases overlap in resource use can be low (Brown \& Lieberman 1973). Where seed consumption by different-sized species is high, selective granivory can affect the composition of the plant community (Brown et al. 1986). Small mammals, especially rodents, may be reliable indicator species because they are abundant enough to allow meaningful statistical analysis of data, belong to different trophic levels and functional guilds, and are easily studied (Brown 1975). In addition, their community characteristics can reflect ecological disturbance in, e.g., conservation areas (Avenant 2000). In spite of this, small mammals are still often overlooked in the planning and conservation of an area (Els \& Kerley 1996). Moreover, in 
South Africa the ecological factors that influence the structure of small mammal communities in geographically separate areas, even with broadly similar habitats, have hardly been investigated (Kerley 1992c).

Rodent species diversity in deserts has been linked to habitat heterogeneity (Rozenzweig \& Winakur 1969), productivity (Brown 1973) or both (Abramsky 1978, 1988). However, species diversity can vary depending on mean annual rainfall, with lower precipitation depressing species numbers and density, and vice versa (Nel 1983; Abramsky 1988). This would be a reflection of changes in primary productivity (Rutherford 1980). In addition, area of habitat has been shown to affect species numbers (Ricklefs \& Lovette 1999; Nee \& Cotgreave 2002; Allen \& White 2003). Williams et al. (2002) state that within limitations set by the regional species pool, local diversity is determined by the habitat capacity (the product of productivity and both spatial and temporal habitat diversity), the habitat itself and the length of time over which the environment has been relatively stable. Ricklefs \& Lovette (1999) concluded that habitat-specialised, largepopulation species are strongly affected by habitat diversity while, in contrast, species with weak habitat specialisation and lowpopulation densities show a strong area effect.

Habitat preference is a reflection of a species's physiological (Bowers \& Brown 1982) and nutritional needs (Kerley \& Erasmus 1992; Kerr \& Packer 1997) set by social interactions (Kotler \& Brown 1988), antipredation factors, competitive ability (Hughes \& Ward 1993; Hughes et al. 1994; Kotler 1984; Lancaster 1996) and successional roles of the animals (Els \& Kerley 1996). It has an adaptive basis (Martin 1998) and ultimately leads to particular species being more abundant in some habitats than others so as to maximise their lifetime reproductive success (Cramer \& Willig 2002). In addition, a number of studies have demonstrated that small mammal community structure is a function of plant architecture (Rosenzweig \& Winakur 1969; Kerley 1992a). As rodents must adapt or became extirpated because they are non-vagile (Mares \& Hulse 1997) a relationship between rodent density and spatial variations, and other demographic parameters on the one hand and habitat heterogeneity on the other can exist (Cueto et al.1995).

Namaqualand covers $\sim 55000 \mathrm{~km}^{2}$ (Van Rooyen et al.1992) and is part of the Succulent Karoo Biome in South Africa (Cowling \& Pierce 1999). Only $1.6 \%$ of this semidesert region has been set aside for formal conservation (Boonzaaier et al. 2002). This area is rich in succulent flora (Van Rooyen et al. 1991; Esler \& Rundel 1997) but few data are available on its small mammals (Dieckmann 1979; Joubert \& Ryan 1999; Schradin 2005; Nel unpubl. data) with even less on small mammal habitat relations and community characteristics.

Here we investigate the effect of habitat features on the numbers and species richness of small mammals, and the effect of food availability on their densities and biomass. We quantify habitat use by small mammals (rodents and elephant shrews of $<200 \mathrm{~g}$ ) in three vegetation types ( $\cong$ habitats). Variables quantified were habitat features, food availability, and small mammal community structure. We determined: a) small mammal species richness, density and biomass in each of the three habitats; b) the numerical contribution of each species to the community in each habitat (species diversity and evenness of representation); obtained c) a measure of the variation between habitats; and $\mathrm{d}$ ) estimated food availability (relative abundance of green foliage, seed and insect numbers, as well as insect biomass). Areas of

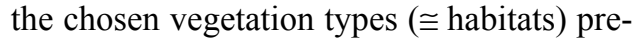
sent within the park were estimated, and the relationship between small mammal community characteristics and habitat and food availability, respectively, determined. In addition, the relative contribution of habitat variation and food availability to species richness, density and biomass was determined. 


\section{Study Area}

Our study area was the Namaqua National Park (NNP), about $495 \mathrm{~km}$ north of Cape Town and $22 \mathrm{~km}$ northwest of Kamieskroon. The park was proclaimed in 1988, with the farm Skilpad (3009'57"S, $\left.17^{\circ} 47^{\prime} 53^{\prime \prime} \mathrm{E}\right)$ as the nucleus. The park was recently enlarged to ca 73619 ha (A. Rossouw pers. comm.).

This semi-desert area is hot with dry summers somewhat tempered by onshore movements of cold air from Benguela current of the South Atlantic. Winters are cold but rainfall sparse and erratic (Schulze 1947), with the highest precipitation-predominantly fog-from May to August. Precipitation increases from west ( $\sim 50 \mathrm{~mm}$ p.a.) to east (>400 $\mathrm{mm}$ in the Kamiesberg) (Cowling et al. 1999). At Skilpad on the eastern edge of the park, rainfall varied from $603.5 \mathrm{~mm}$ in 1986 to $142 \mathrm{~mm}$ in 2000 , with an average of $332.8 \mathrm{~mm}$ per year. Winter temperatures vary between $7-19^{\circ} \mathrm{C}$, and summer temperatures between $20-32^{\circ} \mathrm{C}$ (Schulze 1947). There is also a west to east altitude gradient in the park, from $180 \mathrm{~m}$ a.s.l in the far west, rising to ca $300 \mathrm{~m}$ a.s.l. at Melkboom and then to $750 \mathrm{~m}$ a.s.l. at Skilpad in the foothills of the Kamiesberg. The geology of the Namaqua Rocky Hills is characterised by granite gneiss of the Namaqualand Metamorphic Province (Cowling et al. 1999), and the patchy topography is characterised by broken granite kopjes and plateaux separated by sandy or gravel plains (Dieckmann 1979). The soil is lime rich, weakly developed on a rock substrate (Low \& Rebelo 1996), and a light reddish-brown sand to light sandy loam covered, in some parts, by a thin layer of white quartz pebbles or gravel (Dieckmann 1979).

Dwarf, succulent shrubs and ephemeral species dominate the vegetation (Low \& Rebelo 1996). The numerous ephemeral species (Van Rooyen et al.1990) are able to complete their life cycles rapidly during periods when temperature and moisture conditions are favourable for growth (Van Rooyen et al. 1991). Their leaves, flowers and seeds are important food sources for the resident mammals (Dieckmann 1979).

\section{Methods}

Three sites, each situated in a distinct habitat (vegetation type), were sampled, i.e., in Upland Succulent Karoo, Dry Riverine Shrub and North-western Mountain Renosterveld. The Upland Succulent Karoo or Namaqua Broken Veld is characterised by dome-shaped granite hills. Succulent species, particularly of the Family Mesembryanthemaceae dominate the granite and gneiss-rich soils; grasses are uncommon (Low \& Rebelo 1996) although many species occur. This habitat covers 25767 ha in the park, and grid altitude varied from $308-343 \mathrm{~m}$ a.s.l., with aspects facing $\mathrm{W}, \mathrm{NW}, \mathrm{N}, \mathrm{NE}$ and $\mathrm{E}$.

Dry Riverine Shrub and sweet thorn (Acacia karroo) borders seasonal streams (Theron et al. 1993). This habitat, part of the Upland Succulent Karoo of Low \& Rebelo(1996), is here regarded as a distinct habitat for small mammals. It is characterised by deep sandy soils with grasses, woody shrubs and $\mathrm{A}$. karroo. It covers an area of 3681 ha in the park. Grids were at altitudes from $260-285 \mathrm{~m}$ a.s.1., with aspects facing S-NE.

The North-western Mountain Renosterveld or Mountain Renosterveld is characterised by deep sandy loam soil with Renosterbos Elytropappus rhinocerotis the main plant growth form (Low \& Rebelo 1996). This habitat covers 7362 ha in the park, with grids at $707-751 \mathrm{~m}$ a.s.l. Aspects were E, SE and NW.

At each site, small mammals, habitat features and food availability were sampled in five grids: a large, main one (A) with 70 trap stations, and three subsidiary, smaller ones (B-D) with 20 trap stations each, while a similar grid (E) also sampled small mammals to determine reproductive status and diet. At each site (i.e., habitat), sampling grids were separated by $100 \mathrm{~m}$ to gauge intra-habitat variation, while sites were $10 \mathrm{~km}$ apart and probably have a shared biogeographic history (vide Williams et al. 2002).

All three sites were sampled between 2-19 September 2003 to minimise temporal variation. Small mammals were sampled by means of the capturemark-release-recapture method. Aluminium Sherman live traps $(230 \times 75 \times 90 \mathrm{~mm})$ were used, with traps spaced $15 \mathrm{~m}$ apart in seven rows (grid A), or two rows (grid B-E), and with ten stations per row, i.e. 150 trapping stations per site. In addition, habitat characteristics were measured at randomly selected 
trapping stations within each grid. Voucher specimens for stomach analyses and an accurate determination of reproductive condition ( $\mathrm{Nel}$ et al. 1984; Rautenbach \& Nel 1980) were collected on grid E.

Trap stations were $15 \mathrm{~m}$ apart, giving a sampling plot of $135 \times 90 \mathrm{~m}$ (1.215 ha) for grid A, and $135 \times 15 \mathrm{~m}$ $(0.2025 \mathrm{ha})$ each for grids B-E. Traps were numbered, and baited with a mixture of rolled oats, peanut butter, golden syrup and Bovril (meat and vegetable extract) (Atkinson 1997; Els \& Kerley 1996; Joubert \& Ryan 1999). Traps were set for five consecutive nights and four days, except for grid B (four nights) in the Upland Succulent Karoo and all the grids in the dry Riverine shrub (four nights and three days), to minimise bias due to variability in the relative trapability of each species (Williams et al. 2002). Trapping sessions avoided the night of full moon or nights before and after it (Jensen \& Honess 1995). Traps were checked, rebaited and reset early each morning and during the late afternoons. Captured small mammals were identified, marked by an unique toe-clipped number (Kotler 1984), weighed, sexed, reproductive condition noted and released at the point of capture. Trapping protocol was accepted by South African National Parks. One taxon, Petromyscus, could be identified only to genus level. Nomenclature follows Skinner \& Smithers (1990).

Habitat structure in relation to vegetation structure was described at sampling points randomly selected (Els \& Kerley 1996; Williams et al. 2002).

A robust wire square $\left(1 \mathrm{~m}^{2}\right)$ (Kent \& Coker 1992) was dropped with one corner in a northerly direction from the trap at the 30 selected trap stations in each habitat. The latitude, longitude, and elevation (using GPS), aspect, and visual estimates of percentage vegetation cover by trees, shrubs, and grass; plant litter, edaphic composition (percentage of sand/ gravel/ rock), as well as the height of the dominant plants (i.e. plant species covering most of the area) were recorded. This yielded a measurement of habitat features at different sampling points and combined for the grids in a habitat allowed between-habitat differences to be recognised.

Food availability, taken as foliage, seed and insect availability (Kerley 1992b) was recorded at the same points as the environmental features. A measure of crude seed density within the $1 \mathrm{~m}^{2}$ sampling plots was obtained using five categories: $0=$ no seeds $/ \mathrm{m}^{2}$; $1=1-25$ seeds $/ \mathrm{m}^{2} ; 2=26-75$ seeds $/ \mathrm{m}^{2} ; 3=76-$ 150 seeds $/ \mathrm{m}^{2}$; and $4=>150$ seeds $/ \mathrm{m}^{2}$. Foliage availability represented the percentage green foliage cover within the random squares. Insect availability at sampling points was measured using pitfall traps ( $8 \mathrm{~cm}$ diameter $\times 15 \mathrm{~cm}$ deep plastic containers) half- filled filled with water and dishwashing liquid, and set at the randomly selected points for a five-day period (Cueto et al. 1995). The insects were then removed, preserved in $70 \%$ ethanol, dried, counted, and weighed. As duration of sampling differed between habitats, insect abundance was calculated using a relative density index $(\mathrm{RDI}=$ number of caught individuals/number of traps $x$ number of days involved). Combining values for the three categories gave a crude indication of food availability in each habitat.

Measurements of small mammal populations included trapping success, species richness, species diversity and evenness of representation, abundance, density and biomass. Trapping success (or percentage capture rate) was taken as the number of small mammals captured per 100 trap nights (one trap set for a $12 \mathrm{~h}$ period $=$ one trap night $(\mathrm{Nel} 1978)$ ). Species richness expressed the number of trapped species. Species diversity (number of species and numerical contribution of each to the community) was calculated using the Shannon-Wiener diversity index (Krebs 1999).

For a measure of population size the SchumacherEschmeyer method of abundance (a modification of the Lincoln Index which measures the ratio of marked and unmarked individuals in the population) was used (Krebs 1999). This assumes that the population size remains constant over the sampling period, that sampling is random and that all individuals have an equal chance of capture. For our short study period these assumptions were probably justified. In addition, this method takes into account non-random mixing of marked and unmarked individuals. Small mammal density (individuals captured/ha) and biomass (total mass ( $\mathrm{g}$ ) of all individuals/ ha) were also calculated.

Diet was deduced from stomach analysis, which provide only a relative measure of a species' diet by estimating the contribution (expressed as \%) of seeds (white material), foliage (green material) and insects (black material). Contents of stomachs were mixed and evenly spread in water in a petri dish placed on a grid. The percentage white, green and brown material within six squares were estimated using a stereomicroscope, and the means calculated. Although this is a crude approximation of the actual diet, some idea of the food resources utilised by the different species present at each locality sampled can be gained (Rautenbach \& Nel 1980).

Correlation analyses (Sokal \& Rohlf 1995) helped investigate relations between small mammal community characteristics and environmental features and between features. The $95 \%$ level $(P<0.05)$ was 
Table 1

Small mammal community attributes in Upland Succulent Karoo (USK); Dry Riverine Shrub (DRS); and North Western Mountain Renosterveld (NWMR) in the Namaqua National Park. South Africa. Mean (and range values, where applicable) reflect sampling in five grids, in each habitat

\begin{tabular}{llll}
\hline & \multicolumn{1}{c}{ USK } & \multicolumn{1}{c}{ DRS } & \multicolumn{1}{c}{ NWMR } \\
\hline Trap nights (Total) & 1510 & 1190 & 1530 \\
Trapping success (\%) & $4.4(3.7-12.2)$ & $1.9(0-6.4)$ & $4.5(3.9-11.7)$ \\
No. individuals caught & $60(8-20)$ & $22(0-8)$ & $69(8-26)$ \\
Density (n/ha) & $29.6(12-49)$ & $10.9(0-20)$ & $34.1(21-54)$ \\
Biomass (g/ha) & $1991(399-3859)$ & $459(155-1071)$ & $1493(740-2210)$ \\
Population size (N) & $11(8-17)$ & $5(2-10)$ & $15(8-27)$ \\
Species richness & 4 & 2 & 3 \\
Species diversity H' & 1.78 & 0.658 & 0.971 \\
Evenness E & 0.888 & 0.415 & 0.612 \\
\hline
\end{tabular}

regarded as statistically significant, and applies wherever the term 'significant' is used below.

\section{Results}

Trapping success for 4230 trap nights averaged $4.1 \%$ (range $0-12.2 \%$ within habitats). During 258 capture events 151 individuals (excluding recaptures) of five small mammal species (four rodent and one macroscelidid) were captured. Rodents dominated the catch at all sites in terms of numbers, trap success and biomass (Tables $1 \& 2$ ). Species richness ranged from $2-4$ per habitat, and $0-3$ on any one grid within a habitat. The hairy-footed gerbil, Gerbillurus paeba $(n=84,55.6 \%)$ dominated the community, followed by the Namaqua rock mouse Aethomys namaquensis (48, $31.8 \%$ ). Other species captured were Petromyscus sp. $(n=5)$, Mus indutus $(n=1)$ and Elephantulus edwardii $(n=13)$. The recapture rate (number of recaptures/100 trap nights) was $3.6 \%$. Population size or abundance estimates (mean $N=10$; range $0-27$ ), densities (mean $=24.9 / \mathrm{ha}$; range $0-54.3 / \mathrm{ha})$ and biomass $($ mean $=1314.3 \mathrm{~g}$; range $155-$ $3859 \mathrm{~g} / \mathrm{ha}$ ) of small mammals captured varied between and within habitats (Tables $1 \&$ 2). Only G. paeba occurred in all three habitats; A. namaquensis and E. edwardii in Upland Succulent Karoo and North-west- ern Mountain Renosterveld, while Petromyscus sp. and Mus indutus were only recorded in the Upland Succulent Karoo and Dry Riverine Shrub habitats respectively. Tables $1 \& 2$ give relative capture frequencies and small mammal

\section{Table 2}

Density $(\mathrm{n} / \mathrm{ha})$ and biomass $(\mathrm{g} / \mathrm{ha})$ of small mammal species in Upland Succulent Karoo (USK), Dry Riverine Shrub (DRS), and North-western Mountain Renosterveld (NWMR) in the Namaqua National Park, South Africa. Figures reflect means from 5 grids in each habitat. Total numbers caught in parentheses

\begin{tabular}{lccc}
\hline Species & \multicolumn{3}{c}{ Habitat } \\
\hline & USK & DRS & NWMR \\
\hline Aethomys namaquensis & $(28)$ & & $(20)$ \\
Density & 13.87 & & 9.88 \\
Biomass & 1012.4 & & 584.2 \\
Gerbillurus paeba & $(15)$ & $(21)$ & $(48)$ \\
Density & 7.41 & 10.37 & 23.7 \\
Biomass & 296.1 & 517.8 & 851.8 \\
Mus minutoides & & $(1)$ & \\
Density & & 0.49 & \\
Biomass & & 0.65 & \\
Petromyscus sp. & $(5)$ & & \\
Density & 2.47 & & \\
Biomass & 64.2 & & \\
Elephantulus edwardii & $(12)$ & & $(1)$ \\
Density & 5.93 & & 0.49 \\
Biomass & 618.3 & & 57.3 \\
\hline
\end{tabular}


Table 3

Mean values of each habitat variable for Upland Succulent Karoo (USK); Dry Riverine Shrub (DRS); and North-western Mountain Renosterveld (NWMR) in the Namaqua National Park, South Africa. Values reflect the mean of 30 sampling points in each habitat

\begin{tabular}{lccc}
\hline & USK & DRS & NWMR \\
\hline Total cover (\%) & 24.8 & 25.0 & 49.6 \\
Tree cover (\%) & 1.0 & 11.8 & 12.4 \\
Shrub cover (\%) & & & \\
$\quad$ (Succulents included) & 86.2 & 49.0 & 69.6 \\
$\quad$ Grass cover (\%) & 12.8 & 39.2 & 18.0 \\
Plant litter (\%) & 53.4 & 30.4 & 33.6 \\
Total Basal cover (\%) & 43.0 & 25.2 & 24.8 \\
Sand (\%) & 6.4 & 9.8 & 27.6 \\
Gravel (\%) & 65.4 & 81.6 & 68.0 \\
Rock (\%) & 28.2 & 8.6 & 4.4 \\
$\quad \begin{array}{l}\text { Dominant plant } \\
\text { growth height (m) }\end{array}$ & 0.58 & 0.46 & 1.1 \\
\hline
\end{tabular}

community characteristics in the different habitats.

Total plant cover was the highest in the North-western Mountain Renosterveld and lowest in Upland Succulent Karoo (Table 3). Shrubs dominated in all habitats. Plant litter cover and visible edaphic cover (sand, gravel or rock) was highest in the Upland Succulent Karoo, while the latter was lowest in North-western Mountain Renosterveld, with gravel predominating the non-vegetated areas. The highest dominant plants occurred in the Renosterveld, and the lowest in the Dry Riverine Shrub. There was a significant positive correlation between total plant cover and the height of the dominant plants $(r=0.762)$, and total visible rock cover $(r=0.707)$.

The means and range of green foliage cover were of $46.6 \%$ (34-57), $69.6 \%$ (62-78) and $66.4 \%$ (47-76) for Upland Succulent Karoo, Dry Riverine Shrub and North-western Mountain Renosterveld, respectively. The relative density index (RDI) for insects for the same habitats were (means and ranges) 15.77 (2.6-27.95), 16.9 (12-25.28) and 9.37
(5.6-16.6), while mean mass (and ranges) were $0.3938 \mathrm{~g}(0.0406-0.5415), 0.0981 \mathrm{~g}$ (0.0297-0.2629) and $0.0880 \mathrm{~g}(0.0108-$ $0.2514)$. No seeds were present in the sampling squares in any of the habitats.

Species diversity and species richness were both positively and significantly correlated with shrub cover $(r=0.848$ and $r=0.702$, respectively) while elephant shrew biomass was positively and significantly correlated with both total visible edaphic cover and rock cover ( $r=0.857$ and $r=0.744$, respectively). A number of the small mammal community-environment features were negatively correlated, but significantly so only for species diversity and grass, evenness and grass, density and grass, species richness and grass and total rodent biomass and grass.

Only G. paeba, A. namaquensis and $E$. edwardii were caught in sufficient numbers to analyse the relation between numbers and biomass with environmental features. Gerbillurus paeba numbers and biomass correlated significantly with total plant cover $(r=$ 0.605 and $r=0.845$, respectively), and biomass also with height of the dominant plants $(r=0.829)$. Aethomys namaquensis numbers correlated significantly with shrub cover $(r$ $=0.787)$, and their biomass with rock cover $(r=0.593)$. In addition, numbers and biomass of E. edwardii correlated significantly with total visible edaphic cover $(r=0.942$ and $r=0.857$, respectively), rock cover $(r=$ 0.737 and $r=0.744$, respectively) and insect mass ( $r=0.714$ and $r=0.615$, respectively).

The areas of the three habitats in the park varied from 3681 ha to 25767 ha. All three extended widely outside the park so that the Island Biography Theory cannot be invoked; specific small mammal species occurred in a variety of habitats. Comparing species richness, density and biomass of the small mammals with habitat characteristics and food availability showed different patterns. Food availability had a strong effect on density $(r=0.747,0.01>P>0.001)$ and biomass $(0.714,0.01>P>0.001))$. Habitat characteristics did not show any significant correla- 
tion with density or biomass, but shrub cover was significantly correlated with species richness and diversity $(r=0.702$ and $r=$ 0.848 , respectively). Food availability therefore contributed mostly to density and biomass while habitat characteristics did not contribute significantly to small mammal community structure.

All species trapped were omnivorous, although the rodents were predominantly granivorous and the macroscelid insectivorous. Although no seeds were recorded in the sampling squares, substantial amounts were eaten by $G$. paeba, A. namaquesis, and Petromyscus sp. Gerbillurus paeba diet included seeds (60-80\%), green plant material $(20-40 \%)$ and insects $(\leq 20 \%)$; that of Aethomys namaquesis $\leq 90 \%$ seeds, $\leq 60 \%$ green plant material and $20 \%$ insects; while Petromuscys sp. took $\leq 90 \%$ seeds, $\leq 10 \%$ green plant material and $\leq 20 \%$ insects. Elephantulus. edwardii took mostly insects $(\leq 70 \%)$, and less seed and green plant material ( $\leq 20 \%$ and $30 \%$, respectively) (Table 4 ).

\section{Discussion}

Our study recorded fewer species than others in Namaqualand and other arid or semi-arid parts of South Africa (Dieckman 1979; Nel 1983; Kerley \& Erasmus 1992; Joubert \& Ryan 1999), and far fewer than the diverse small mammal fauna of North American deserts (Brown \& Lieberman 1973), but not that of the Argentinian Monte Desert (Mares 1976). This could be due to previous disturbance brought about by intensive smallstock grazing before the park was promulgated (Avenant 2000), or trapping during a trough in small mammal density resulting from the preceding extensive drought. During 2003 rainfall at the Springbok weather station ca. $65 \mathrm{~km}$ to the north of the NNP was the lowest since 1984, with $5 \mathrm{~mm}$ recorded in autumn and winter (April-July), whereas the long-term average (since 1960) is $102 \mathrm{~mm}$ p.a. This resulted in the local extinction of the bush Karoo rat, Otomys unisulcatus, in the Goegap Nature Reserve some $20 \mathrm{~km}$ east of Springbok (Schradin

\section{Table 4}

Contribution (mean \% volume) of seeds (white material), foliage (green material) and insects (brown material) to the diet of small mammals in the Namaqua National Park, South Africa

\begin{tabular}{|c|c|c|c|c|}
\hline Species & $\mathrm{n}$ & Seeds & Foliage & Insects \\
\hline Gerbillurus paeba & 18 & 57 & 22 & 21 \\
\hline Aethomys namaquensis & 10 & 64.6 & 26.1 & 9.3 \\
\hline Petromyscus & 3 & 90.67 & 1.67 & 7.67 \\
\hline Elephantulus $k$ edwardii & 4 & 27.25 & 28.5 & 44.25 \\
\hline
\end{tabular}

2005). At Skilpad in the east of the NNP, average annual rainfall from 1986-2002 was $333 \mathrm{~mm}$, but only $184 \mathrm{~mm}$ from Jan-Sept 2003. Long-term trapping in the SW Kalahari (Nel 1983, Nel unpubl.) have shown that species richness and density of small mammals fluctuate in concert with precipitation, a feature perhaps common to deserts (Abramsky 1988). Such fluctuations could be a secondary response tracking fluctuating primary productivity (Rutherford 1980), which would be mirrored by seed availability (Reichman 1984; Price \& Reichman 1987) and insect biomass. While seed banks in North American deserts can be large (Price \& Joyner 1997), seed availability, where recorded, is much lower in South African arid and semi-arid regions (Milton \& Dean 1990; Kerley 1992b). This could account for the low species richness and low numbers found in our study, as the four rodent species recorded were all primarily granivorous. In addition, seeds of different size tend to be partitioned between differentsized rodent species (Brown \& Lieberman 1973; Bowers \& Brown 1982). Seed density in our study grids was too low for seeds to be separated into different-sized samples, but size differences between the coexisting granivorous species were large: $M$. indutus = $6.1 \mathrm{~g}$, Petromyscus sp. $=21 \mathrm{~g}$, G. paeba $=$ $26 \mathrm{~g}$ and $A$. namaquensis $=47 \mathrm{~g}$ (i.e. more than the $1.5 \mathrm{x}$ differences in mass suggested to allow coexistence (Brown 1973)); while Petromyscus also showed some habitat separation from the other rodents. Although species richness was low, the capture success of $6.1 \%$ was somewhat higher than that 
recorded in the Karoo (Kerley 1992b; Kerley \& Erasmus 1992), where capture successes of $4.8 \%$ and $2.9 \%$, respectively, were obtained. Our higher figure, however, could be an artifact of the prevailing low seed availability which possibly enhanced use of artificially-provided food sources, such as bait in traps.

All species captured were omnivorous to a greater or lesser extent, but the rodents were primarily granivorous and the macroscelidid primarily insectivorous, corresponding with results from other studies in arid southern Africa (Nel 1978; Kerley 1992a, 1992b); Kerley (1992a) has argued that strictly granivorous rodents are less well represented in arid and semi-arid southern Africa than in North American and Israeli deserts. In contrast to results of Kerley (1992a) from the Nama Karoo, in our study G. paeba in Succulent Karoo had a predominantly granivorous diet, as was also found in the SW Kalahari (Nel 1978). As in other studies (Brown \& Kurzius 1987; Kotler \& Brown 1988; Morris 1996), common species (G. paeba and $A$. namaquensis) were distributed through all or most vegetation types while the other species (M. indutus, Petromyscus and E. edwardii) had lower densities and were confined to a particular habitat. In common with results from similar studies in southern Africa (Nel 1983; Kerley \& Erasmus 1992) which recorded fluctuating species richness and density of small mammals, emigration from refugia rather than dispersal from a source to a sink (Johnson et al. 2005) probably account for this phenomenon.

Microhabitat features such as vegetation structure, cover and height, relatively humidity, litter depth and foliage height diversity are related to the life form and growth form of plant species within a plant community (Els \& Kerley 1996) and affect the small mammal community structure (Price 1978; Rosenzweig \& Winakur 1967). Similar correlations emerged in our study. Small mammal diversity and richness correlated significantly with shrub cover (the dominant plant growth form), with macroscelidid biomass correlating significantly with total basal and rock cover. Such correlations suggest that shrub cover in our study area and probably most of the Succulent Karoo Biome is a dominant factor affecting small mammal species diversity, while basal and rock cover determine macroscelidid biomass. Therefore selecting shrub cover would presumably reflect both physiological and anti-predator adaptations of small mammals, as well as being a measure of forage availability.

Along with habitat characteristics correlates, food availability also influences small mammal densities and biomass (Kotler \& Brown 1988). As expected, macroscelidid biomass correlated significantly with insect mass. When the different species were contrasted with environmental features, each showed a significant correlation with some form of environmental feature. This clearly reflects the different physiological, nutritional, social and anti-predator requirements of the small mammal species in question.

The linear relationship between species richness and habitat area (Allen \& White 2003; Bruun 2001; Nee \& Cotgreave 2002), as well as species richness and habitat diversity, has been extensively studied (Brown \& Kurzius 1987; Cramer \& Willig 2002; Cueto et al. 1995; Kerr \& Packer 1997; Kotler \& Brown 1988; Williams et al. 2002). There is some debate about the relationship between habitat diversity and species-area relationship (SPAR) and their effect on species richness (Ricklefs \& Lovette 1999; McGuinness 2000; Van Rensburg et al. 2002). In our study the habitats sampled, although varying in size, extended far outside the park so that the species-area relationship cannot be invoked. Our study found no correlation between species richness and habitat characteristics. This could be the result of the very low species richness of small mammals recorded due to long-term low primary productivity, especially so in the preceding year (Brown \& Davidson 1977), all species being habitat generalists (Morris 1996), low spatial heterogeneity within and between the sample plots in a specific habitat, a lack of habitatspecificity in most species occurring, the 
habitats sampled being non-island or virtual island habitats, or a combination of these factors.

Small mammal densities and biomass correlated with food availability, which supports our hypothesis that density and biomass are dependent on food availability. However, investigations that studied the simultaneous effect of area, habitat diversity and food availability on species characteristics, including small mammals, are limited. Longterm studies elsewhere in arid southern Africa (Nel 1978, 1983) have emphasized that once-off sampling of small mammal populations in arid and semi-arid regions in South Africa can bring about misleading results, as numbers of constituent species in a given community fluctuate dramatically in response to rainfall fluctuations. This leads to changes in inter-specific interactions, changes in habitat utilisation and probably also changes in the diet of particular species over time. The results of our survey, undertaken during a long-term drought and at an unknown point in the fluctuating cycle of the community as a whole may therefore not be an accurate reflection of long-term small mammal community composition and dynamics at our study site in the Succulent Karoo.

\section{Acknowledgements}

We thank SANParks for allowing the study and providing facilities and accommodation, and especially Andre Rossouw for providing accommodation at Melkboom, and other members of the Namaqua National Park for their assistance. We are greatly indebted to G.I.H. Kerley and R.J. van Aarde for providing detailed critical comments and many helpful suggestions on earlier drafts.

\section{References}

ABRAMSKY, Z, 1978. Small mammal community ecology. Changes in species diversity in response to manipulated productivity. Oecologia 34: 113-123.
ABRAmSKy, Z. 1988. The role of habitat and productivity in structuring desert rodent communities. Oikos 52: 107-114.

Allen, A. P. \& E.P. White. 2003. Effects of range size on species-area relationships. Evolutionary Ecology Research 5: 493-499.

ATKINSON, R.P.D. 1997. Practical aspects of trapping small mammals in the tropics. Journal of Zoology 242: 390-394.

AVENANT, N.L. 2000. Small mammal community characteristics as indicators of ecological disturbance in the Willem Pretorius Nature Reserve, Free State, South Africa. South African Journal of Wildlife Research 30: 26-33.

BAR, Y., Z. ABRAMSKY \& Y. GUTterman. 1984. Diet of gerbilline rodents in the Israeli desert. Journal of Arid Environments 7: 371-376.

Boonzaaier, M., P. Margerman, R. Smart. \& M. NoRVAL. 2002. Succulent Karoo ecosystem plan. Sub-regional report, Namaqualand.

Bowers, M. A. \& J.H. Brown. 1982. Body size and coexistence in desert rodents: chance or community structure. Ecology 63: 391-400.

BRown, J.H. 1973. Species diversity of seed-eating desert rodents in sand dune habitats. Ecology 54: 775-787.

Brown, J. H. 1975. Geographical ecology of desert rodents. Pp. 315-341. In: Cody, M. L. \& J.M. DiAMOND (eds.). Ecology and evolution of communities. New Haven, Connecticut: Belknap Press.

BRown, J.H. \& G.A. LiEBERMAN. 1973. Resource utilization and coexistence of seed-eating rodents in sand dune habitats. Ecology 54: 788-797.

BRown, J.H. \& D.W. Davidson. 1977. Competition between seed-eating rodents and ants in desert ecosystems. Science 196: 880-882.

Brown, J.H., O.J. Reichman. \& D.W. Davidson. 1979. Granivory on desert ecosystems. Annual Review of Ecology and Systematics 10: 201-207.

BRown, J.H., D.W. DAVIDSON, J.C. Munger \& R.S. INOUYE. 1986. Experimental community ecology: the desert granivore system. Pp. 41-61 In: Diamond, J. \& T.J. CASE (eds.). Community Ecology. New York: Harper \& Row.

Brown, J. H. \& M.A. KuRzIUs. 1987. Composition of desert rodent faunas: combinations of coexisting species. Annales Zoologica Fennica 24: 227-237.

BRUUN, H.H. 2001. Determinants of species richness in patches of grassland and heathland in Himmerland (Denmark). Nordic Journal of Botany 21: 607-613.

Cowling, R.M., K.J. Esler \& P.W. Rundel. 1999. Namaqualand, South Africa - an overview of a unique winter-rainfall desert ecosystem. Plant Ecology 142: 3-21.

Cowling, R. M. \& S. PierCe. 1999. Namaqualand: a succulent desert. Cape Town: Fernwood Press. 
Cramer, M. J. \& M.R. Willig. 2002. Habitat heterogeneity, habitat associations, and rodent species diversity in a sand-shinnery-oak landscape. Journal of Mammalogy 83: 743-753.

Cueto, V. R., M. Cagnoni \& M.J. Piantanida. 1995. Habitat use of Scapteromys tumidus (Rodentia: Cricetidae) in the delta of the Paranà River, Argentina. Mammalia 59: 25-34.

DieCKMANN, R. C. 1979. Note on the smaller mammals of the Hester Malan Nature Reserve, Springbok, Namaqualand. South African Journal of Zoology 14: 85-89.

Els, L. M. \& G.I.H. KerLey. 1996. Biotic and abiotic correlates of small mammal community structure in the Groendal Wilderness Area, Eastern Cape, South Africa. Koedoe 39: 121-130

Esler, K. J. \& P.W. Rundel. 1997. So what is so special about Namaqualand? South African Journal of Science 93:488.

Hughes, J. J. \& D. WARD. 1993. Predation risk and distance to cover affect foraging behaviour in Namib Desert gerbils. Animal Behaviour 46: 1243-1245.

Hughes, J. J., D. Ward \& M.R. Perrin. 1994. Predation risk and competition affect habitat selection and activity of Namib Desert gerbils. Ecology 75: 1397-1405.

Jensen, S. P. \& P. Honess. 1995. The influence of moonlight on vegetation height preference and trappability of small mammals. Mammalia 59: 35-42.

Johnson, C.N., K. Vernes. \& A. PAYne. 2005. Demography in relation to population density in two herbivorous marsupials: testing for source-sink dynamics versus independent regulation of population size. Oecologia 143: 70-76.

Joubert, D. F. \& P.G. RYAN. 1999. Differences in mammal and bird assemblages between commercial and communal rangelands in the Succulent Karoo, South Africa. Journal of Arid Environments 43: 287-299.

Kam, M., I.S. Khokhlova. \& A.A. Degen. 1997. Granivory and plant selection by desert gerbils of different body size. Ecology 78: 2218-2229.

Kent, M. \& P. CoKER. 1992. Vegetation Description and Analysis. London: Belhaven Press.

KERLEY, G.I.H. 1992a. Trophic status of small mammals in the semi-arid Karoo, South Africa. Journal of the Zoological Society, London 226: 563572.

KeRLEY, G.I.H. 1992b. Small mammal seed consumption in the Karoo, South Africa: further evidence for divergence in desert biotic processes. Oecologia 89: 471-475.

KERLEY, G.I.H. 1992c. Ecological correlates of small mammal community structure in the semi-arid Karoo, South Africa. Journal of the Zoological Society, London 227: 17-27.
Kerley, G.I.H. \& T. Erasmus. 1992. Small mammals in the semi-arid Karoo, South Africa: biomass and energy requirements. Journal of Arid Environments 22: 251-260.

Kerr, J. T. \& L. PACKer. 1997. Habitat heterogeneity as a determinant of mammal species richness in high-energy regions. Nature 385: 252-254.

KotLER, B.P. 1984. Risk of predation and the structure of desert rodent communities. Ecology 65: 689-701.

Kotler, B.P. \& J.S. Brown. 1988. Environmental heterogeneity and the coexistence of desert rodents. Annual Review of Ecology and Systematics 19: 281-307.

Krebs, C. J. 1999. Ecological Methodology. Menlo Park, California: Longman.

LANCASTER, J. 1996. Scaling the effects of predation and disturbance in a patchy environment. Oecologia 107: 321-331.

LANDRY, S.L. 1970. The Rodentia as omnivores. Quarterly Review of Biology 45:35-372.

Low, A. B. \& A.G. Rebelo. 1996. Vegetation of South Africa, Lesotho and Swaziland. Pretoria: Department of Environmental Affairs and Tourism.

MARES, M.A. 1976. Convergent evolution of desert rodents: multivariate analyses and zoogeographic implications. Paleobiology 2:39-63.

Mares, M. A. \& A.C. Hulse. 1977. Patterns of some vertebrate communities in creosote bush deserts. Pp. 209-226. In: MABRY, T. J., J.H. HunZIKER \& D.R. DIFEO (eds.). Creosote bush: biology and chemistry of Larrea in New World deserts. Stroudsburg, Pennsylvania: Dowden, Hutchinson \& Ross.

MARTIN, T. E. 1998. Are microhabitat preferences of coexisting species under selection and adaptive? Ecology 79: 656-670.

MCGUINNESS, K.A. 2000. Distinguishing area and habitat heterogeneity effects: a simulation test of the MacNally and Watson (1997) protocol. Austral Ecology 25: 8-15.

Milton, S. \& W.J.R. Dean. 1990. Seed production in rangelands of the Karoo. South African Journal of Science 86: 231-233.

Morris, D.W. 1996. Coexistence of specialist and generalist rodents via habitat selection. Ecology 77: 2352-2364.

Nee, S. \& P. Cotgreave. 2002. Does the species/ area relationship account for the density/ area relationship. Oikos 99: 545-551.

NEL, J.A.J. 1978. Habitat heterogeneity and changes in small mammal community structure and resource utilization in the southern Kalahari. Bulletin of the Carnegie Museum of Natural History 6: 118-131.

NEL, J.A.J. 1983. Changes in population structure of Kalahari rodents over a decade: 1970-1980. 
Annale Musee Royal de l'Afrique Centrale Sciences Zoologiques 237: 173-178.

Nel, J.A.J., I.L. Rautenbach, D.A. Els \& G. DE GRAAFF. 1985. Rodents and other small mammals of the Kalahari Gemsbok National Park. Koedoe 27 (Supplement): 229-235.

PRICE, M.V. 1978. The role of microhabitat in structuring desert rodent communities. Ecology 59: 910-921.

Price, M.V. \& S.H. JenKins. 1986. Rodents as seed consumers and dispersers. Pp. 191-235. In: Murray, D.R. (ed.). Seed Dispersal. Sydney: Academic Press.

Price, M.V. \& O.J. Reichman. 1987. Spatial and temporal heterogeneity in Sonoran Desert seed pools, and implications for heteromyid rodent foraging. Ecology 68: 1797-1811.

Price, M. V. \& J.W. Joyner. 1997. What resources are available to desert granivores: Seed rain or soil bank? Ecology 78: 764-773.

RautenBACH, I.L. \& J.A.J. NeL. 1980. Mammal diversity and ecology in the Cedarberg Wilderness area, Cape Province. Annals of the Transvaal Museum 32: 101-124.

REICHMAN, O.J. 1984. Spatial and temporal variation in seed distributions in desert soils. Journal of Biogeography 11: 1-11.

Ricklefs, R. E. \& I.J. LovetTE. 1999. The roles of island area per se and habitat diversity in the species-area relationships of four lesser Antillean faunal groups. Journal of Animal Ecology 68: 1142-1160.

RosenzWeig, M. L. \& J. WinAKuR. 1969. Population ecology of desert rodent communities: habitats and environmental complexity. Ecology 50: 558-572.

RuTHERFORD, M.C. 1980. Annual plant productionprecipitation relations in arid and semi-arid regions. South African Journal of Science 76: 53-56.

Schradin, C. 2005. Nest-site competition in two diurnal rodents from the Succulent Karoo of
South Africa. Journal of Mammalogy 86: 757-762.

Schulze, B. R. 1947. The climates of South Africa according to the classifications of Koppen and Thornthwaite. South African Geographical Journal 29: 32-42.

SkinNer, J. D. \& R.H.N. Smithers. 1990. The Mammals of the Southern African Subregion. Pretoria: University of Pretoria.

SoKAL, R.R. \& F.J. RoHLF. 1995. Biometry: The Principles and Practice of Statistics in Biological Research. New York: Freeman.

THeron, G.K., M.W. VAN RoOyen \& N. VAN RoOYEN. 1993. Skilpad Wildflower Reserve: Botanical Survey, Department of Botany, University of Pretoria, Pretoria.

Van Rensburg, B. J., S.L. Chown \& K.J. Gaston. 2002. Species richness, environmental correlates and spatial scale: A test using South African birds. The American Naturalist 159: 566-577.

VAn Rooyen, M. W., N. GrobbelaAr, G.K. Theron. \& N. VAN RoOYEN. 1991. The ephemerals of Namaqualand: effects of photoperiod, temperature and moisture stress on development and flowering of three species. Journal of Arid Environments 20: 15-29.

Van Rooyen, M. W., N. Grobbelaar, G.K. Theron \& N. VAN RoOYEN. 1992. The ephemerals of Namaqualand: effect of germination date on development of three species. Journal of Arid Environments 22: 51-66.

Van Rooyen, M. W., G.K. Theron \& N. GrobbeLAAR. 1990. Life form and dispersal spectra of the flora of Namaqualand, South Africa. Journal of Arid Environments 19: 133-145.

Williams, S. E., H. Marsh \& J. Winter. 2002. Spatial scale, species diversity and habitat structure: Small mammals in Australian Tropical Rain Forest. Ecology 83: 1317-1329. 